\title{
Lights and shadows on the conservation of a rock art cave: The case of Lascaux Cave
}

\author{
Fabiola Bastian $^{1}$ and Claude Alabouvette ${ }^{1}$
}

\begin{abstract}
:
Bastian F. and Alabouvette C. 2009. Lights and shadows on the conservation of a rock art cave: The case of Lascaux Cave. International Journal of Speleology, 38 (1), 55-60. Bologna (Italy). ISSN 0392-6672.

Lascaux Cave was discovered in 1940. Twenty years after the first microbial contamination signs appeared. In the last forty years the cave suffered different fungal invasions. Here we discuss the past, present and future of the cave and the conservation of its rock art paintings to the light of data obtained using culture-dependent and -independent methods.
\end{abstract}

Keywords: Rock art paintings, bacteria, fungi, benzalkonium chloride, conservation of paintings

Received 21 May 2008; Revised 16 September 2008; Accepted 17 September 2008

\section{INTRODUCTION}

Bacteria and fungi are capable of colonizing almost every niche. Caves are not an exception and are distinctive habitats with nearly complete darkness, relatively constant air and water temperatures, high moisture, and a poor supply of easily degradable organic matter. Caves were suggested to be considered as extreme environments for life because they provide ecological niches for highly specialized microorganisms (Schabereiter-Gurtner et al., 2004). Reactive mineral surfaces and solute-rich groundwater provide sufficient energy sources for chemolithoautotrophic growth at the rock surface and can serve as the base for a cave food web, increasing both food quality and quantity (Poulson \& Lavoie, 2000; Kinkle \& Kane, 2000). Subsurface microorganisms generally seem to be active at very low but significant rates and several investigations indicate that chemolithoautotrophs form a chemosynthetic base providing substrates for heterotrophic life (Pedersen, 2000).

Movile Cave, Romania, a sulfidic cave system, was the first documented chemolithoautotrophically-based cave and groundwater ecosystem (Sarbu et al., 1996). Chemolithoautotrophic microbial growth has been found in other active sulfidic cave systems, including Parker Cave (Angert et al., 1998), the Frasassi Caves, Italy (Vlasceanu et al., 2000; Sarbu et al., 2000), Cueva de Villa Luz, Mexico (Hose et al., 2000), Cesspool Cave (Engel et al., 2001), and the flooded Nullarbor caves, Australia (Holmes et al., 2001). In Lechuguilla Cave (New Mexico, USA) the organic input is limited due

1. INRA UMR Microbiologie du Sol et de l'Environnement BP 86510, F 21065 DIJON Cedex to the depth, but bacterial and fungal colonisation is relatively extensive (Cunningham et al., 1995). They suggested that chemolithoautotrophs are present in the ceiling-bound residues and could act as primary producers in a unique subterranean microbial food chain (Engel et al., 2004).

Bartonetal. (2007) showed that in a cave environment, the microbial community subsisted by using barely perceptible carbon and energy sources, including organics entering the system through percolation, and the presence of volatile organic molecules within the atmosphere. In some caves the organic material present in the dripping waters have a phenolic and aromatic nature (Saiz-Jimenez \& Hermosin, 1999; Sylvia et al., 1999). Also, different studies have shown that in some caves microorganisms are not properly chemolithoautotrophs, but instead are translocated soil heterotrophs, chemoorganotrophs or fecal coliform bacteria from contaminated surface water that are associated to surface inputs (Laiz et al. 1999; Simon et al., 2003).

Some caves are open for tourism because they are particularly interesting for their prehistoric paintings as the Lascaux cave (Fig. 1) or their mineralogical formations, such as stalactites. Efforts are made to determine human impact on cave conservation, and to prevent detrimental effects due to human activities. Indeed, microenvironmental data such as temperature, $\mathrm{CO}_{2}$ concentration, moisture and atmospheric pressure, clearly showed the negative influence of visitors (Hoyos et al. 1998).

In Kartchner Caves, Arizona, Ikner et al. (2007) showed that bacterial diversity generally decreased as human impact increased. The degree of human impact 


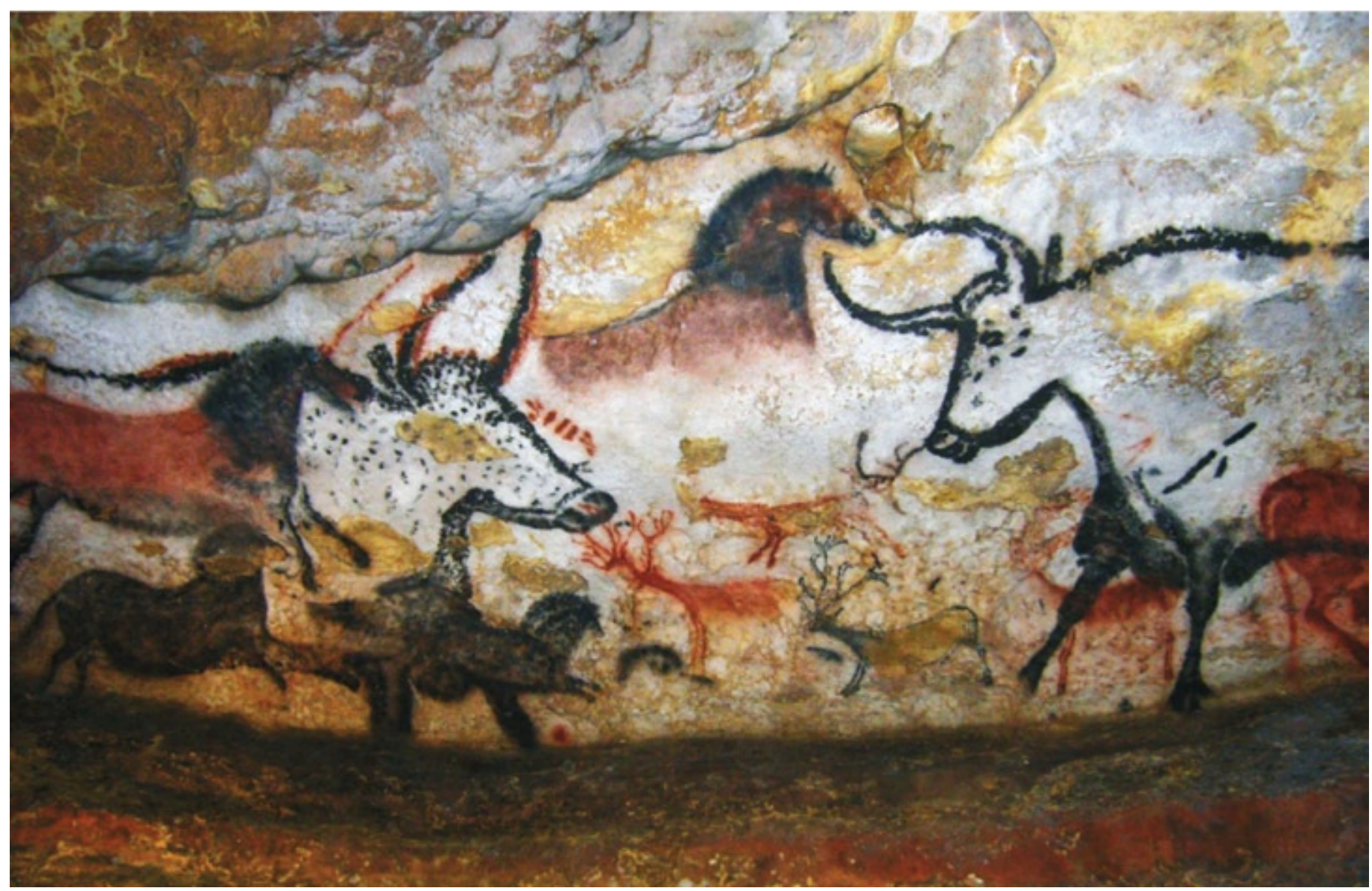

Fig. 1. World-famous prehistoric paintings of the Lascaux Cave (Nov. 2004). The cave has been closed to the public since the sixties because of microbial development.

was also reflected in the phylogeny of the isolates recovered, Proteobacteria dominating in communities exposed to high levels of human contact. This study also showed that although the abundance of bacteria along the cave include microbes of the environment rather than microorganisms of anthropogenic origin, it is likely that their presence is a consequence of increased availability of organic matter introduced by visitors.

Inappropriate artificial illumination of archaeological remains and their interior works of art (Albertano, 1991; Albertano and Bruno, 2003; Albertano et al., 2003; Ariño et al., 1997) resulted in the uncontrolled development of photosynthetic microorganisms, primarily cyanobacteria and microalgae (HernandezMariné et al., 2003; Hoffmann 2002, Lefèvre 1974, Ortega-Calvo et al., 1993, Roldan et al., 2004), forming greenish biofilms that contribute to surface deterioration. These organisms feature a matrix composed primarily of exopolymers that are involved in the resistance of biofilms to adverse abiotic conditions as well as in attachment (Albertano et al., 2003; Decho, 2000; Tamaru et al., 2005). Control efforts usually focus on cleaning damaged surfaces or on chemical treatments that have little efficacy against biofilms (Costerton et al., 1999; Kumar \& Kumar, 1999). Hence, there is an ever-increasing interest in the development of alternative strategies for preventing and minimizing biofilm development.

In the last decade Lascaux Cave suffered progressive microbial colonization. Here we discuss on the circumstances that conducted to the present-day situation.

\section{LASCAUX CAVE: A HISTORIC OVERVIEW}

The Cave of Lascaux was discovered in 1940. As soon as it was opened to the public, it attracted many visitors and the microbiological balance was changed. Starting in the early nineteen sixties, lighting adaptations for visits provoked the growth of a green biofilm on the wall paintings, identified as being produced by algae (Lefèvre, 1974). This green biofilm and other deteriorations linked to tourism led to the closure of the cave in 1963. This damage was attributed to perturbations induced by visitors' breath and the lighting which favoured microbial and algal growth. Between July and September 2001, the first evidence appeared of a fungal invasion of Fusarium solani and the associated bacterium Pseudomonas fluorescens (Allemand \& Bahn, 2005; Orial \& Mertz, 2006). In August 2001, the first biocidal treatments were started but the rapid extension of the fungal colonies in the soil prompted an intensive treatment of quicklime (Sire, 2006). Since 2001 some black stains were detected on the ceiling and the banks of the passage, and their abundance increased in 2007. Melanised fungi were mostly responsible for these stains and during the recent months a debate was initiated in several international media venues on the origin of these black spots and whether a biocidal treatment was needed or not. 


\section{PRESENT-DAY SITUATION IN LASCAUX CAVE}

Although culture-dependent and -independent methods are used for the study of microorganisms in soils and caves we rely on molecular methods which allow for the characterization of organisms that are difficult, if not impossible, to cultivate (Lopez Garcia et al., 2003). At present the application of molecular techniques is filling the existing gap between the detection of cultured and uncultured microorganisms (Gonzalez \& Saiz-Jimenez, 2004). Unfortunately molecular methods can create some biases and underestimates particular microbial groups, especially if groups have abundance $\leq 10^{7}$ cells per volume (Speksnijder et al., 2001).

In Lascaux Cave, classic methods based on isolation of microorganisms were previously used (Orial \& Mertz, 2006; Dupont et al., 2007), evidencing the presence of a Fusarium solani species complex and associated Pseudomonas fluorescens. We used molecular biology techniques based on DNA extraction followed by PCR amplification of $16 \mathrm{~S}$ rRNA or $18 \mathrm{~S}$ rRNA to identify bacteria and fungi respectively. These microorganisms were identified by cloning sequencing of the DNA either isolated from a pure culture or extracted from sediment samples. The preliminary results obtained following these two approaches are well correlated and revealed a great diversity of both bacteria and fungi. They showed similarities in community structure when the communities are sampled from areas with a similar range of moisture, even if the substrata is not the same, but their structures are significantly different, when they are taken from areas with different moisture levels, even if the substrata is the same.

The most abundant bacteria genera found in Lascaux Cave were Ralstonia spp. and Pseudomonas spp. both belonging to the taxonomic group Proteobacteria, which were not equally distributed all along the cave, although present in almost all the samples studied. In addition, some Stenotrophomonas spp. were identified ( $12 \%$ in one sample from the Painted Gallery). It is known that members of this genus carry out denitrification reactions, with conversion of ammonia to nitrous oxide, and also play a role in the denitrification of complex organic compounds, such as nitrobenzene (Barton et al., 2007). A few phylotypes of Herbaspirillum sp. and Janthinobacterium sp. were found. These genera are related to nitrogen assimilating species (Barton et al., 2007). A more exhaustive phylogenetic examination of Lascaux Cave bacteria is being carried out and will be reported elsewhere.

Heterogeneity in distribution is observed in fungi. The most abundant phylotype Penicillium namyslowskii is nearly absent in the Great Hall of Bulls but strongly represented in the Chamber of Felines. Fungi such as Aspergillus niger and some Penicillium spp. often found in Lascaux Cave are known to solubilise and mineralize phosphorus from inorganic and organic pools (Van Breemen et al., 2000, Vassilev et al., 1996, Wakelin et al., 2004). In Lascaux, several species of amoebae were detected, and some arthropods were identified, especially Collembola which are known to play a role in dissemination of fungal spores and bacteria.
Previous studies (Holmes et al., 2001; SchabereiterGurtner et al., 2002a, 2002b, 2004; Northup et al., 2003; Engel et al., 2004, Zhou et al., 2007) using culture-independent methods, have revealed that bacteria belonging to Proteobacteria, Bacteroidetes, and Actinobacteria were usually found on different cave substrata. Among them, Proteobacteria were reported to be the dominant bacteria and could have a key role in the cave biogeochemical processes. In agreement with this statement, Proteobacteria is the most abundant group identified in Lascaux Cave where it represents more than $90 \%$ of the bacteria. In Altamira Cave (Spain) Proteobacteria represented about $50 \%$ of sequences identified, and surprisingly a practically unknown group of microorganisms, the Acidobacteria, represented almost $25 \%$ of the total (Schabereiter-Gurtner et al. 2002a). Acidobacteria is a unique bacterial group since most of this bacterial division is only known from the $16 \mathrm{~S}$ rDNA sequences of uncultured microorganisms (Gonzalez \& SaizJimenez, 2004). Studies based on culture-independent methods make more difficult valid statements about the ecological role that these organisms might play in the environment.

In Lascaux Cave, the huge presence of Pseudomonas spp. and Ralstonia spp. are in agreement with Ikner's results (Ikner et al., 2007), however these bacteria were also present in less impacted areas. It is, in fact, really difficult to obtain quantitative results concerning the absolute contributions of the various anthropogenic organic matter sources on the development of bacteria and fungi in caves. Most of the time data concerning the initial stage, before opening the cave to tourism are missing, making the demonstration of the real impact of tourism in a cave impossible. In contrast, Lechuguilla Cave has had limited human impact and represents an excellent site to investigate the microbial biodiversity in the absence of human activity (Northup et al., 2003). On the other hand, Lascaux Cave offers the possibility of studying different areas with varying degrees of human exposure. Indeed, two areas, the Chamber of Felines and the Shaft of the Dead Man, were never opened to public, although the Great Hall of Bulls and the Painted Gallery were heavily visited for almost 20 years.

\section{CONSERVATION EFFORTS IN LASCAUX CAVE}

In Lascaux, the native organisms have been radically disturbed by repeated application of biocides. At first, combined sprays of streptomycin and penicillin were applied to control bacteria followed by formaldehyde applications against algae. Starting in 1969 a programme of periodic maintenance and cleaning was adopted, based on formaldehyde spraying on the paths. In 2001, the cave was rapidly invaded by a white fungus (Fig. 2), identified as Fusarium solani (Dupont et al., 2007) a soil borne fungus, which covered the floor of the cave and was treated with application of quicklime to stop the development of the strong invasion. Later on, several applications of benzalkonium chloride were made (Fig. 3), since this 


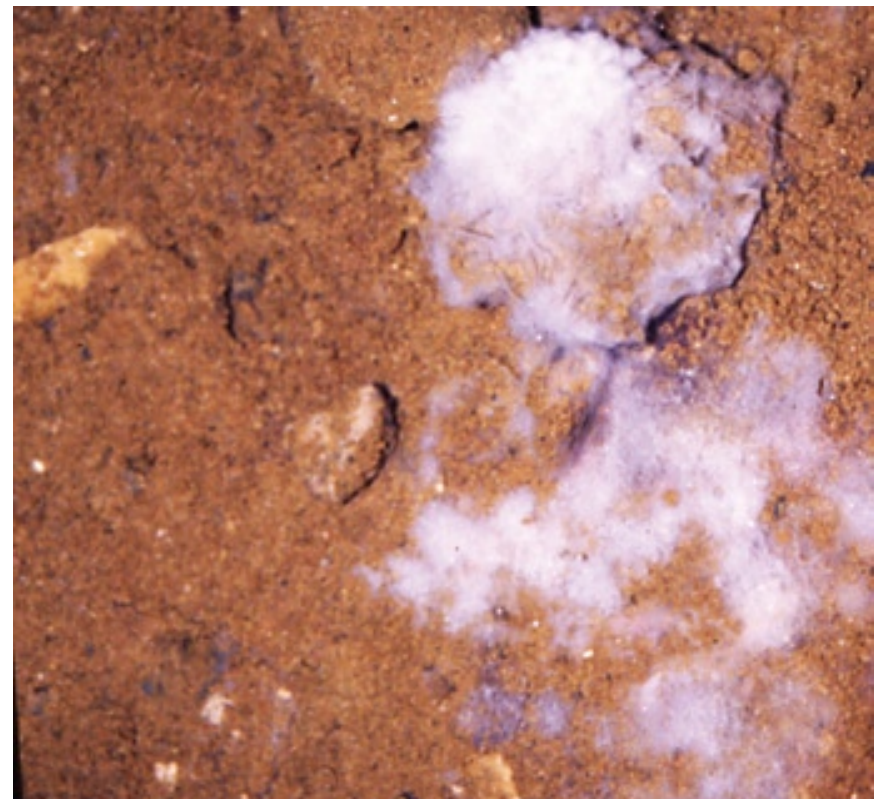

Fig. 2. Colonies of white fungus growing on the soil in 2001 and identified as Fusarium solani.

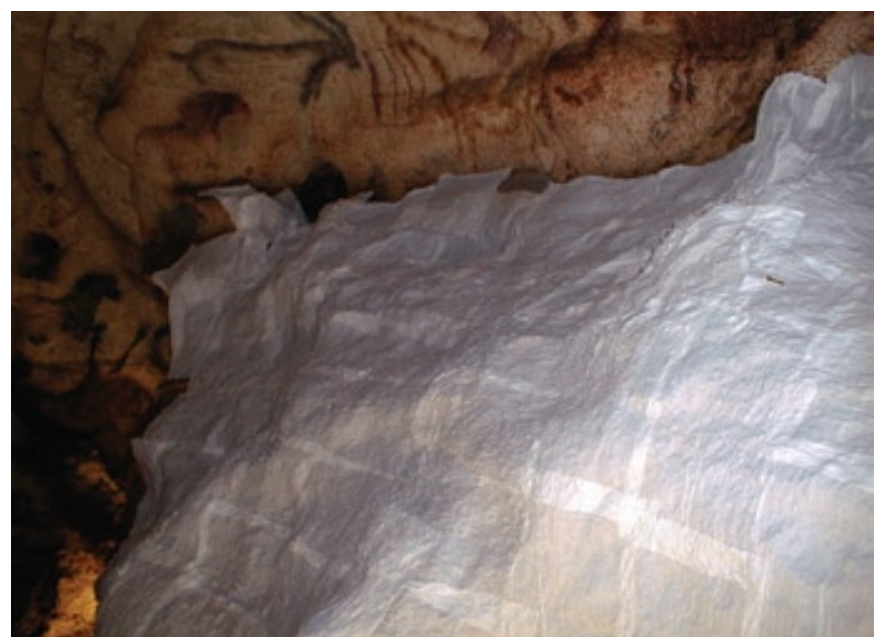

Fig. 3. Applications of pads containing biocides on undecorated walls only in Lascaux Cave in 2001-2002.

molecule was demonstrated "in vitro" as having a good efficacy against Fusarium solani. However, in situ the efficacy of this molecule was limited, possibly because the fungus was associated with bacteria in a biofilm, making it less susceptible to the molecule. Moreover, some bacteria present in the biofilm (Pseudomonas fluorescens) are able to degrade this type of molecule (Nagai et al., 1996).

An intriguing question concerns the origin of $F$. solani and the reasons for its explosive development in 2001. It was proposed that the invasion of $F$. solani resulted from an accidental introduction from the external environment, but this hypothesis has not been confirmed, since Dupont et al., (2007) demonstrated that the population isolated from the cave was not homogeneous. They found 19 different genotypes among the 36 isolates studied and a different localization inside the cave for these different genotypes.

Being heterotrophic $F$. solani needs organic carbon as nutrient. Thus, an organic carbon source must have been present in the cave, but its origin remains unknown. Several hypotheses can be suggested: the percolation water, the biocide residues from previous sprays (it has been shown that some strains of Fusarium solani are able to grow on agar media containing formaldehyde or ethanol as sole source of carbon), or even the activity of chemolithotrophic bacteria could have provided a source of organic carbon useful for promoting the growth of the fungi.

\section{CONCLUSIONS}

In the Lascaux Cave, the first problem that attracted the attention of researchers was the "maladie verte", due to algal development (Lefèvre, 1974). Later on, fungal colonies appearing as white or/and black spots created the main conservation problem. The sole aim of the treatments was only to eradicate algae or fungi. However until recently nobody had studied the interactions between all the organisms present in the cave. Bacteria are present on the rock surfaces and sometimes they constitute mucous biofilms but no one has been interested in the composition of the biofims, which associate bacteria, fungi, and probably protozoa. Only recently a research project has been funded which aims at studying the ecology of the cave, including interactions between microorganisms (bacteria and fungi), other organisms (protozoa and arthropods) and human presence.

Currently the most important point of interest in Lascaux is the development of "black spots" corresponding to the growth of melanised fungi (Fig. 4). Melanin synthesis is associated with reduced fungal susceptibility to a variety of stresses that fungi may encounter in the environment, including predation by amoebae and UV light, between others. An interesting result is that certain bacterial species may serve as sources of substrates for melanisation of different fungi in the environment (Frases et al., 2006). This hypothesis should be explored. Among the fungi detected in the black spots in the Lascaux Cave, Verticillium sp. and Scolecobasidium sp. were identified. Phylogenetic analyses will be necessary to determine if these fungus results from an accidental introduction into the cave or if, as $F$. solani, they preexisted in the cave before becoming visible. However it must be noticed that the genus Scolecobasidium has been shown to be able to degrade surfactants of similar effects to the biocides applied in the cave. Thus, its current development might have been favoured by biocide applications.

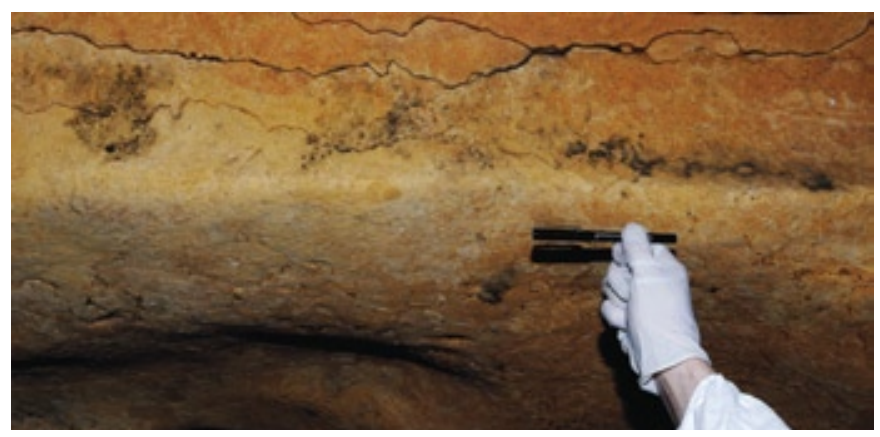

Fig. 4. A wall in Lascaux Cave showing "black spots" produced by melanised fungi. 
Trying to control by artificial (chemical) means the development of microorganisms in a cave environment is not a realistic approach since we do not understand the whole ecological functioning of the cave. Understanding interactions (i) between and among organisms (ii) between microorganisms, and macroorganisms, (iii) between the climatic parameters, the nature of the rock surface and the microbial development and (iv) the impacts of the biocide application on microbial balance are crucial to decide if application of biocides will be useful or deleterious to the cave.

In conclusion, further multifaceted (microbiological, ecological, physiological, geological, molecular biological, etc.) research is needed to characterize the microbial ecosystem and yield new information regarding the metabolic functions of the different microorganisms inhabiting in such a complex environment. Results of this multidisciplinary research are needed to identify indicators of the sanitary state of the cave and to propose decision-making tools for the conservation of the paintings. This is a fascinating challenge for all the scientists working in caves.

\section{ACKNOWLEDGEMENTS}

The first author was supported by a project financed by the Ministry of Culture and Communication, through the Direction Régionale des Affaires Culturelles d'Aquitaine, France. Authors thank Penny Boston for valuable comments on the manuscript and C. Saiz-Jimenez for useful discussions.

Pictures protected by copyright: Ministère de la Culture et de la Communication : DRAC d'Aquitaine and/or Centre National de la Préhistoire.

\section{REFERENCES}

Albertano P. 1991 - Effects of monochromatic lights on four species of Leptolyngbya. Archives für Hydrobiologie, Algological Studies, 64: 199-214.

Albertano P. \& Bruno L. 2003 - The importance of light in the conservation of hypogean monuments. In: SaizJimenez C. (Ed.) - Molecular Biology and Cultural Heritage. Lisse: Balkema: 171-177.

Albertano P., Moscone D., Palleschi G., Hermosín B., Saiz-Jimenez C., Sanchez-Moral S., HernándezMariné M., Urzi C., Groth I., Shroeckh V., Saarela M., Mattila-Sandholm T., Graziottin F., Gallon J.R., Bisconti F. \& Giuliani R. 2003 - Cyanobacteria attack rocks (CATS): control and preventive strategies to avoid damage caused by cyanobacteria and associated microorganisms in Roman hypogean monuments. In: Saiz-Jimenez C. (Ed.) - Molecular Biology and Cultural Heritage. Lisse: Balkema: 151-162.

Allemand L. \& Bahn P.G. 2005 - Best way to protect rock art is to leave it alone. Nature, 433: 800.

Angert E.R., Northup D.E., Reysenbach A.-L., Peek A.S., Goebel B.M. \& Pace N.R. 1998 - Molecular phylogenetic analysis of a bacterial community in Sulphur River, Parker Cave, Kentucky. American Mineralogist, 83: 1583-1592.
Ariño X., Hernandez-Marine, M. \& Saiz-Jimenez, C. 1997 - Colonization of Roman tombs by calcifying cyanobacteria. Phycologia, 36: 366-373.

Barton H.A., Taylor N.M., Kreate M.P., Springer A.C., Oehrle S.A. \& Bertog J.L. 2007 - The impact of host rock geochemistry on bacterial community structure in oligotrophic cave environments. International Journal of Speleology, 36: 93-104.

Costerton J. W., Stewart P.S. \& Greenberg E.P. 1999 - Bacterial biofilms: a common cause of persistent infections. Science, 284: 1318-1322.

Cunningham K.I., Northup D.E., Pollastro R.M., Wright W.G. \& LaRock E.J., 1995 - Bacteria, fungi and biokarst in Lechuguilla Caves, Carlsbad Caverns National Park, New Mexico. Environmental Geology, 25: 2-8.

Decho A.W. 2000 - Microbial biofilms in intertidal systems: an overview. Continental Shelf Research, 20: 12571273.

Dupont J., Jacquet C., Dennetiere B., Lacoste S., Bousta F., Orial G., Cruaud C., Couloux A. \& Roquebert M.F. 2007 - Invasion of the French Paleolithic painted cave of Lascaux by members of the Fusarium solani species complex. Mycologia, 99: 526-533.

Engel A.S., Porter M.L., Kinkle B.K. \& Kane T.C. 2001 Ecological assessment and geological significance of microbial communities from Cesspool Cave, Virginia. Geomicrobiology Journal, 18: 259-274.

Engel A.S., Porter M.L., Stern L.A., Quinlan S. \& Bennett P.C. 2004 - Bacterial diversity, and ecosystem function of filamentous microbial mats from aphotic (cave) sulfidic springs dominated by chemolithoautotrophic "Epsilonproteobacteria". FEMS Microbiology Ecology, 51: 31-53.

Frases S., Chaskes S., Dadachova E. \& Casadevall A. 2006 - Induction by Klebsiella aerogenes of a melaninlike pigment in Cryptococcus neoformans. Applied and Environmental Microbiology, 72: 1542-1550.

Gonzalez J.M. \& Saiz-Jimenez C. 2004 - Microbial diversity in biodeteriorated monuments as studied by denaturing gradient gel electrophoresis. Journal of Separation Science, 27: 174-180

Hernandez-Marine M., Clavero E. \& Roldan M. 2003 Why there is such luxurious growth in the hypogean environments. Archives für Hydrobiologie, Algological Studies, 109: 229-239.

Hoffmann L. 2002 - Caves and other low-light environments: aerophytic photoautotrophic microorganisms. In: Bitton G. (Ed.) - Encyclopedia of Environmental Microbiology. New York: John Wiley, pp. 835-843.

Holmes A.J., Tujula N.A., Holley M., Contos A., James J.M., Rogers P. \& Gillings M.R. 2001 - Phylogenetic structure of unusual aquatic microbial formations in Nullarbor caves, Australia. Environmental Microbiology 3: 256-264.

Hose L.D., Palmer A.N., Palmer M.V., Northup D.E., Boston P.J. \& DuChene H.R. 2000 - Microbiology and geochemistry in a hydrogen-sulphide rich karst environment. Chemical Geology, 169: 399-423.

Hoyos M., Soler V., Cañaveras J.C., Sánchez-Moral S. \& Sanz-Rubio E. 1998 - Microclimatic characterization of a karstic cave: human impact on microenvironmental parameters of a prehistoric rock art cave (Candamo Cave, northern Spain). Environmental Geology, 33: 231-242. 
Ikner L., Toomey R., Nolan G., Neilson J., Pryor B. \& Maier R. 2007- Culturable microbial diversity and the impact of tourism in Kartchner Caverns, Arizona. Microbial Ecology, 53: 30-42.

Kinkle B. \& Kane T.C. 2000 - Chemolithoautotrophic microorganisms and their potential role in subsurface environments. In: Wilkens H., Culver D.C. \& Humphreys W.F., (Eds.) - Ecosystems of the World. Amsterdam: Elsevier: 30, 309-318.

Kumar R. \& Kumar A. 1999 - Biodeterioration of stone in tropical environments. An overview. Los Angeles: The Getty Conservation Institute.

Laiz L., Groth I., Gonzalez I. \& Saiz-Jimenez C. 1999 - Microbiological study of the dripping waters in Altamira cave (Santillana del Mar, Spain). Journal of Microbiological Methods, 36: 129-138.

Lefèvre M. 1974 - La maladie verte de Lascaux. Studies in Conservation, 19: 126-156.

López-García P., Philippe H., Gail F. \& Moreira D. 2003 - Autochthonous eukaryotic diversity in hydrothermal sediment and experimental microcolonizers at the Mid-Atlantic Ridge. Proceedings of the National Academy of Sciences of the United States of America, 100: 697-702.

Nagai K., Ohta S., Zenda H., Matsumoto H. \& Makino M. 1996 - Biochemical characterization of a Pseudomonas fluorescens strain isolated from a benzalkonium chloride solution. Biological and Pharmaceutical Bulletin, 19: 873-875.

Northup D.E., Barns S.M., Yu L.E.,. Spilde M.N, Schelble R.T. \& Dano K.E. 2003 - Diverse microbial communities inhabiting ferromanganese deposits in Lechuguilla and Spider Caves. Environmental Microbiology, 5: 1071-1086.

Orial G. \& Mertz J.D. 2006 - Etude et suivi des phénomènes microbiologiques. Monumental 2: 76-86.

Ortega-Calvo J. J., Hernandez-Marine M. \& Saiz-Jimenez C. 1993 - Cyanobacteria and algae on historic buildings and monuments. In: Garg K.L., Arai H. \& Rai B. (Eds.) Recent Advances in Biodeterioration and Biodegradation. Calcutta: Naya Prokash: vol. I: 173-203.

Pedersen K. 2000 - Exploration of deep intraterrestrial microbial life: current perspectives. FEMS Microbiology Letters, 185: 9-16

Poulson T.L. \& Lavoie K.H. 2000 - The trophic basis of subsurface ecosystems. In: Wilkens H., Culver D.C. \& Humphreys W.F., (Eds.) - Ecosystems of the World. Amsterdam: Elsevier: 30: 231-249.

Roldan M., Clavero E., Castel S. \& Hernandez-Marine M. 2004 - Biofilms fluorescence and image analysis in hypogean monuments research. Archives für Hydrobiologie, Algological Studies, 111: 127-143.

Saiz-Jimenez C. \& Hermosin B., 1999 - Thermally assisted hydrolysis and methylation of dissolved organic matter in dripping waters from the Altamira Cave. Journal of Analytical and Applied Pyrolysis, 49: 337-347.

Sarbu S.M., Kane T.C. \& Kinkle B.K. 1996 - A chemoautotrophically based cave ecosystem. Science, 272: 1953-1955.
Sarbu S.M., Galdenzi S., Menichetti M. \& Gentile G. 2000 - Geology and biology of Grotte di Frasassi (Frasassi Caves) in Central Italy, an ecological multi-disciplinary study of a hypogenic underground karst system. In: Wilkens H., Culver D.C. \& Humphreys W.F., (Eds.) Ecosystems of the World. Amsterdam: Elsevier: 30: 361-381.

Schabereiter-Gurtner C., Saiz-Jimenez C., Piñar G., Lubitz W. \& Rölleke S. 2002a - Altamira Cave Paleolithic paintings harbour partly unknown bacterial communities. FEMS Microbiology Letters, 211: 7-11.

Schabereiter-Gurtner C., Saiz-Jimenez C., Piñar G., Lubitz W. \& Rölleke S. 2002b - Phylogenetic 16S rRNA analysis reveals the presence of complex, and partly unknown bacterial communities in Tito Bustillo Cave, Spain, and on its Paleolithic paintings. Environmental Microbiology, 4: 392-400.

Schabereiter-Gurtner C., Saiz-Jimenez C., Piñar G., Lubitz W. \& Rolleke S. 2004 - Phylogenetic diversity of bacteria associated with Paleolithic paintings and surrounding rock walls in two Spanish caves (Llonin and La Garma). FEMS Microbiology Ecology, 47: 1-13.

Simon K.S., Benfield E.F. \& Macko S.A. 2003 - Food web structure and the role of epilithic biofilms in cave streams. Ecology, 84: 2395-2406.

Sire M.A. 2006 - De l'élimination des champignons au constat d'état. Monumental, 2: 68-75.

Speksnijder A., Kowalchuk G. A., De Jong S., Kline E., Stephen J. R. \& Laanbroek H. J. 2001 - Microvariation artifacts introduced by PCR and cloning of closely related 16S rRNA gene sequences. Applied and Environmental Microbiology, 67: 469-472.

Sylvia D.M., Fuhrmann J.J., Hartel P.G. \& Zuberer D.A. 1999 - Principles and Applications of Soil Microbiology. Upper Saddle River: Prentice Hall

Tamaru Y., Takani Y., Yoshida T. \& Sakamoto T. 2005 - Crucial role of extracellular polysaccharides in desiccation and freezing tolerance in the terrestrial cyanobacterium Nostoc commune. Applied and Environmental Microbiology, 71: 7327-7333.

Van Breemen N., Finlay RF., Lundstrom U., Jongmans A.G., Giesler R. \& Olsson M. 2000 - Mycorrhizal weathering: a true case of mineral plant nutrition. Biogeochemistry, 49: 53-67.

Vassilev N., Franco I., Vassileva M. \& Azcon R. 1996 Improved plant growth with rock phosphate solubilized by Aspergillus niger grown on sugar-beet waste. Bioresource Technology, 55: 237-241

Vlasceanu L., Sarbu S.M., Engel A.S. \& Kinkle B.K. 2000 - Acidic cave-wall biofilms located in the Frasassi Gorge, Italy. Geomicrobiology Journal, 17: 125-139.

Wakelin S.A., Warren R.A., Harvey P.R. \& Ryder M.H., 2004 - Phosphate solubilization by Penicillium spp. closely associated with wheat roots. Biology and Fertility of Soils, 40: 36-43.

Zhou J.P., Gu Y.Q., Zou C.S. \& Mo M.H. 2007 Phylogenetic diversity of bacteria in an earth-cave in Guizhou Province, Southwest of China. Journal of Microbiology, 45: 105-112. 